\title{
MUNKAÉRTÉK PREFERENCIÁK ÉS AZ AZOKAT BEFOLYÁSOLÓ SZOCIÁLIS TÉNYEZŐK ÖSSZEHASONLÍTÓ VIZSGÁLATA \\ A Debreceni EgYeteM EgéSZSÉGügYi FöISKOLA ÉS A KOLOZSVÁRI BABEŞ-BOLYAI TUDOMÁNYEGYETEM HALLGATÓI KÖRÉBEN
}

\author{
Szabó Hajnalka - Orosz Hajnalka - Kiss János
}

\begin{abstract}
This project was completed by the Debreceni Egyetem Pályakép és Munkaérték Kutatási Projekt, TÁMOP-4.2.2. B. Work value preferences, factors that influenced the choice of chosing a faculty or university and the social background of the students were examined among the students of University of Cluj-Napoca Babeş-Bolyai, National University of Uzhhorod, II. Rákóczi Ferenc Hungarian Collage of Beregszász and University of Debrecen. This study examined the social background and its effects for work value of students of University of Cluj-Napoca Babeş-Bolyai who take part in the Romanian education and students of University of Debrecen Health Faculty.
\end{abstract}

Keywords: national research, value of work, comparison, social background DOI: $10.19055 / \mathrm{ams} .2013 .4 / 10 / 3$

\section{BEVEZETÉS}

Kutatásunk a Debreceni Egyetem Pályakép és Munkaérték Kutatási Projekt, TÁMOP 4.2.2. B pályázat keretein belül valósult meg, mely során a kolozsvári Babeş-Bolyai Tudományegyetem, a beregszászi II. Rákóczi Ferenc Magyar Főiskola az Ungvári Nemzeti Egyetem és a Debreceni Egyetem hallgatói körében vizsgáltuk a munkaérték preferenciákat, az egyetem, illetve szak választást befolyásoló tényezőket, továbbá a hallgatók szociális hátterét.

Jelen tanulmány a kolozsvári Babeş-Bolyai Tudományegyetem román nyelvü képzésében résztvevő és a Debreceni Egyetem Egészségügyi Főiskola hallgatóinak társadalmi hátterét és azok a munkaérték preferenciákra gyakorolt hatását vizsgálja. 
Vizsgált társadalmi tényezők:

1. Milyen fenntartású általános és középiskolába járt?

2. Mi a szülők legmagasabb iskolai végzettsége?

3. Hol laknak a szülei?

4. Szüleivel egy háztartásban lakik-e?

\section{A KÉRDöÍVRöL}

A vizsgálat során egy 2 részből álló kérdőívet használtunk, mely tartalmazza a Superféle munkaérték kérdőív második változatát, továbbá 53 kérdést, melyek kitérnek a hallgatók szociális körülményeire, a szak, illetve az egyetem választást befolyásoló tényezőkre, a szakról/egyetemről alkotott véleményre, továbbá a hallgatók végzés utáni elképzeléseire.

D. E. Super 1962-ben publikálta a munkaértékekkel kapcsolatos kérdőívét, melynek második, 1968/69-es változata került adaptálásra hazánkban.

Maga a kérdőív 45 állításból áll, melyeket a válaszadó 1-től 5.ig értékelhet, az állítások 15 értékkört takarnak, amik értéke 3-15 pontig terjedhet. (Fónai- Kiss-MártonZolnai, 2010)

Értékkörök: szellemi ösztönzés, altruizmus, anyagiak, változatosság, függetlenség, presztízs,esztétikum, társas kapcsolatok,játékosság, önérvényesítés, hierarchia, humán értékek, munkateljesítmény, irányítás kreativitás.

\section{MinTA ÉS MÓDSZER}

A két intézmény hallgatói a kérdőívet önkéntes jelentkezés alapján, anonim módon töltötték ki.

Teljes minta: 176 fö

Babeş-Bolyai Tudományegyetem: 73 fö

Debreceni Egyetem: 103 fö

Alkalmazott statisztikai eljárások:

Eloszlás, átlag, szórás meghatározása

Faktoranalízis

Keresztösszefüggések meghatározása

A kapott adatokat SPSS 19 program segítségével nyertük.

A megkérdezésre a 2011/2012- es tanévben került sor a Debreceni Egyetem Egészségügyi Karán, másod éves ápolás és betegellátás alapszakos, védőnő és szociális munkás szakos hallgatók, illetve a kolozsvári Babes-Bolyai Tudományegyetem román nyelvü képzésén résztvevő hallgatók körében. 


\section{A VIZSGált KAROKRóL}

A Debreceni Egyetem 1914-ben kezdte meg müködését. Kezdetben három karon indultak képzések, ami napjainkig 15 karrá nőtte ki magát és mintegy negyvenezer hallgatót oktat.

A Debreceni Egyetem Egészségügyi Kara nyíregyházi székhellyel 1990-ben nyitotta meg kapuit a tanulni vágyók számára. Kezdetben két szakon (védőnő és általános szociális munkás) indult meg a tanítás 60 hallgatóval és 5 oktatóval.

Az intézmény létrehozásának főbb céljai a következők voltak:

- $\quad$ szakképzett munkaerő biztosítása az egészségügy számára

- $\quad$ munkanélküliség csökkentése

- a Kelet- magyarországi régió fejlesztése

- $\quad$ a felsőoktatási intézmények számának növelése

1991-ben újabb szakkal bővült a képzés (egészségügyi ügyvitelszervezö), ami nemcsak a régióban volt új, hanem a rendszerváltó országokban is, hiszen ekkoriban nem létezett még hasonló szak.

1993 és 1999 között további szakokkal bővült az Egészségügyi Kar: diplomás ápoló, orvosdiagnosztikai laboratóriumi analitikus, mentőtiszt, gyógytornász.

2000 és 2006 között nagy átalakításokon ment át a kar, 4 alapszakot alakítottak ki (ápolás és betegellátás, egészségügyi gondozás és prevenció, egészségügyi szervező, szociális munka) melyek 7 szakirányt foglaltak magukba ( ápoló, szülésznő, mentötiszt, gyógytornász, védőnő, egészségügyi ügyvitelszervező, egészségbiztosítás, egészségturizmus).

2007-ben karunkon indult az ország első mesterszak Egészségügyi Szociális Munka néven, 2010-ben pedig Ápolás mesterszak indult.

A 2010/11-es tanévben a folyamatos fejlődésnek és bővülésnek köszönhetően szükségessé vált két intézet, az Egészségtudományi- és a Szociális- és Társadalomtudományi Intézet létrehozása, melyhez négy, illetve két tanszék tartozik. További változások történtek, az Orvosdiagnosztikai Laboratóriumi Analitikus képzés az Általános Orvostudományi Kar, a Gyógytornász szak pedig a Népegészségügyi Kar részeként müködik tovább. (Fábián, 2010)

A kolozsvári Babeş-Bolyai Tudományegyetem közel 140 éves múltra tekint vissza és Románia vezető egyetemei közé sorolható. Nevét Bolyai János matematikus és Victor Babeş orvos után kapta. Erdély számos területén rendelkezik kihelyezett részlegekkel.

Különlegessége abban is rejlik, hogy az itt tanulni vágyók német, román, illetve magyar nyelven tanulhatnak és választhatják ki a nekik megfelelöt a 72 alapszak és 31 mesterszak közül. 61 szakon magyarul folyik az oktatás, amit 2008-ban közel 7500 tanuló választott, illetve 1500 magyar nemzetiségü hallgató vett részt román nyelvü képzésben. A romániai magyar egyetemisták 80\%-a ezen az egyetemen szerzi a felsőfokú képesítését.

A rendszerváltás után igény született arra, hogy Kolozsváron létesüljön egy teljesen magyar nyelvủ állami egyetem, azonban az akkori román kormány nem látta szükségszerủnek az elképzelést, csak magyar nyelven müködő külön intézmény nem jött létre. 
1997-ben az egyetem magyar oktatói kezdeményezték, hogy az egyetem magyar része kapjon önálló döntési keretet (Szilágyi-terv), a kezdeményezés nem valósult meg, de elismerték a magyar tagozat létezését.

\section{A hallgatóK SZOCiO-DEMOGRÁFiai MUTATóI}

A kérdőívek felvétele során próbáltunk törekedni arra, hogy közel azonos elemszámú almintákat kapjunk. Az alapsokaság 58,5\%-a a magyar, 41,5\%-a a román mintához tartozik.

A nemek szerinti eloszlás tekintetében hasonló eredményeket kaptunk mind a két mintán, itt is megfigyelhető az elnőiesedés jelensége. A magyar minta 12,6\%-a férfi, 87,4 \%-a nő. A kolozsvári mintából 3-man nem válaszoltak, 12,3\%-a férfi, 83,6 \%-a nő.

A magyar mintába tartozó szinte összes hallgató a 18-25 éves korosztályba tartozik, az egyetlen kivétel egy 28 éves hallgató volt. A kolozsvári minta már nagyobb vál tozatosságot mutat, 69 választ kaptunk, ebből 61 tartozik a 18-25 éves korosztályba, 3man a 26-30, továbbá 5-en a 35-50 évesek csoportjába.

A debreceni hallgatók közül mindannyian az egészségügyi karra járnak, ebböl 23,3 $\%$ az ápoló, $28,2 \%$ a mentőtiszt, $20,4 \%$ a szülésznő, $24,3 \%$ a védőnő, 3,9 \% a szociá lis munka képzésben vesznek részt.

A hallgatók 80,3 \%-a a szociológia és szociális munka, 1,4\%-a a bölcsésztudományi, müvészeti, 2,8\%-a társadalomtudományi, jogi 15,5\%-a teológiai kar tagja.

1. táblázat Általános iskola típusa szerinti eloszlás ( elemszám)

\begin{tabular}{|c|c|c|c|c|c|}
\hline & $\begin{array}{c}\text { önkormány- } \\
\text { zati, állami }\end{array}$ & egyházi & $\begin{array}{c}\text { alapítványi, } \\
\text { magán }\end{array}$ & egyéb & összesen \\
\hline debreceni & 97 & 6 & 0 & 0 & 103 \\
\hline kolozsvári & 67 & 1 & 1 & 3 & 72 \\
\hline összesen & 164 & 7 & 1 & 3 & 175 \\
\hline
\end{tabular}

Forrás: TÁMOP 4.2.2. B pályázat adatbázisa

Nem fedezhető fel nagy különbség a kolozsvári és debreceni hallgatók között abban a tekintetben, hogy milyen fenntartású általános iskolába jártak. Nagy többségük önkormányzati/ állami általános iskolába járt, és igen kis arányban jártak egyházi vagy ala pítványi/ magán iskolába. (1. táblázat)

A legtöbben gimnáziumban végezték a középfokú tanulmányaikat, és közel azonos számú diák járt szakközépiskolába a magyarországi hallgatók közül. A román hallgatók közül is a legtöbben a gimnáziumot, és igen kis számban szakközépiskolát és szakmunkás képzést választották.

Hat- illetve nyolcosztályos gimnáziumba csak magyar hallgatók jártak. (2. táblázat) 
2. táblázat Középiskola típusa szerinti megoszlás (elemszám)

\begin{tabular}{|c|c|c|c|c|c|c|}
\hline & $\begin{array}{c}\text { szakmun- } \\
\text { kásképző }\end{array}$ & $\begin{array}{c}\text { szakkö- } \\
\text { zépiskola }\end{array}$ & $\begin{array}{c}\text { gimnázi- } \\
\text { um }\end{array}$ & $\begin{array}{c}\text { hatosztá- } \\
\text { lyos gim- } \\
\text { názium }\end{array}$ & $\begin{array}{c}\text { nyolcosz- } \\
\text { tályos } \\
\text { gimnázi- } \\
\text { um }\end{array}$ & összesen \\
\hline debreceni & 1 & 37 & 45 & 4 & 3 & 90 \\
\hline kolozsvári & 2 & 3 & 62 & 0 & 0 & 67 \\
\hline összesen & 3 & 40 & 107 & 4 & 3 & 157 \\
\hline
\end{tabular}

Forrás: TÁMOP 4.2.2. B pályázat adatbázisa

3. táblázat Szüleivel egy háztartásban lakik? ( elemszám)

\begin{tabular}{|c|c|c|c|c|c|c|c|}
\hline & igen & $\begin{array}{c}\text { nem, } \\
\text { albérletben } \\
\text { lakik }\end{array}$ & $\begin{array}{c}\text { nem, } \\
\text { kollégi- } \\
\text { umban } \\
\text { lakik }\end{array}$ & $\begin{array}{c}\text { nem, } \\
\text { mert már } \\
\text { önálló } \\
\text { háztartá- } \\
\text { sa van }\end{array}$ & $\begin{array}{c}\text { nem, } \\
\text { mert } \\
\text { mindkét } \\
\text { szüleje } \\
\text { meghalt }\end{array}$ & egyéb & összesen \\
\hline debreceni & 61 & 19 & 18 & 1 & 1 & 2 & 102 \\
\hline kolozsvári & 25 & 16 & 21 & 4 & 1 & 3 & 70 \\
\hline összesen & 86 & 35 & 39 & 5 & 2 & 5 & 172 \\
\hline
\end{tabular}

Forrás: TÁMOP 4.2.2. B pályázat adatbázisa

A magyar hallgatók több, mint fele a szüleivel él egy háztartásban, közel ugyanannyian laknak albérletben, mint kollégiumban és igen kevés százalékuk tart fenn önálló háztartást, ami adódhat a hallgatók szociális körülményeiböl. (3. táblázat)

A kolozsvári minta is hasonló a magyarhoz, azonban itt már több diák tart fenn önálló háztartást.

\section{A szülök iskolai végzettsége}

A magyar mintán a szakmunkás végzettségü apák száma magasan kiemelkedik, ezt követik az érettségivel, majd az általános iskolai bizonyítvánnyal rendelkezők. Igen kevesen szereztek főiskolai vagy egyetemi végzettséget.

A kolozsvári mintán az apák iskolai végzettségét tekintve vezetnek az érettségivel rendelkezők és a szakmunkások. Itt már nagyobb arányban fordulnak elő az apák főiskolai vagy egyetemi diplomával, habár hárman nem rendelkeznek semmilyen végzettséggel sem. (4. táblázat) 
4. táblázat Az apák legmagasabb iskolai végzettsége ( elemszám)

\begin{tabular}{|c|c|c|c|c|c|c|c|c|}
\hline & $\begin{array}{c}\text { nem } \\
\text { tudja }\end{array}$ & $\begin{array}{c}\text { nem be- } \\
\text { fejezett } \\
\text { elemi } \\
\text { és álta- } \\
\text { lános }\end{array}$ & $\begin{array}{c}\text { befeje- } \\
\text { zett ál- } \\
\text { talános, } \\
\text { elemi }\end{array}$ & polgári & $\begin{array}{c}\text { szak- } \\
\text { mun- } \\
\text { kás, ta- } \\
\text { nonc }\end{array}$ & $\begin{array}{c}\text { érettsé- } \\
\text { gi }\end{array}$ & $\begin{array}{c}\text { föisko- } \\
\text { la }\end{array}$ & egyetem \\
\hline debreceni & 1 & 0 & 7 & 1 & 56 & 28 & 2 & 5 \\
\hline kolozsvári & 5 & 3 & 5 & 1 & 18 & 21 & 6 & 4 \\
\hline összesen & 6 & 3 & 12 & 2 & 74 & 49 & 8 & 9 \\
\hline
\end{tabular}

Forrás: TÁMOP 4.2.2. B pályázat adatbázisa

5. táblázat Az édesanyák legmagasabb iskolai végzettsége ( elemszám)

\begin{tabular}{|c|c|c|c|c|c|c|c|c|}
\hline & $\begin{array}{c}\text { nem } \\
\text { tudja }\end{array}$ & $\begin{array}{c}\text { nem be- } \\
\text { fejezett } \\
\text { elemi } \\
\text { és álta- } \\
\text { lános }\end{array}$ & $\begin{array}{c}\text { befeje- } \\
\text { zett ál- } \\
\text { talános, } \\
\text { elemi }\end{array}$ & polgári & $\begin{array}{c}\text { szak- } \\
\text { mun- } \\
\text { kás, ta- } \\
\text { nonc }\end{array}$ & $\begin{array}{c}\text { érettsé- } \\
\text { gi }\end{array}$ & fóiskola & $\begin{array}{c}\text { egye- } \\
\text { tem }\end{array}$ \\
\hline debreceni & 0 & 0 & 10 & 0 & 25 & 47 & 11 & 7 \\
\hline kolozsvári & 5 & 6 & 3 & 1 & 17 & 15 & 4 & 8 \\
\hline összesen & 5 & 6 & 13 & 1 & 42 & 62 & 15 & 15 \\
\hline
\end{tabular}

Forrás: TÁMOP 4.2.2. B pályázat adatbázisa

Az édesanyák iskolai végzettségét tekintve a legmagasabb értéket az érettségi (47), majd a szakmunkás (25) képzésben résztvevők érték el, ezt követte a föiskolai, egyetemi képzés és befejezett általános iskola a debreceni hallgatók körében.

A kolozsvári diákoknál a legmagasabb arányban a szakmunkás bizonyítványt és érettségit szerzett anyák vannak, majd ezt követi az egyetemi képzésben résztvettek és végül hatan nem szereztek semmilyen végzettséget sem. (5. táblázat) 


\section{A SUPER MUNKAÉRTÉK VIZSGÁlAT EREDMÉNYEI}

Az értékkörök rangsorában magasan vezet az altruizmus 13,30-as átlaggal, ezt követi a társas kapcsolatok, és az önérvényesítés. Az utolsó helyen áll a játékosság 7,25-ös átlaggal, ezt előzi meg a humán értékek és esztétikum. Ellentmondás fedezhető fel az értékkörök átlagában, hiszen míg az altruizmus az első, addig a humán értékek az utolsó előtti helyen áll. (6. táblázat)

6. táblázat Az értékkörök rangsora a Debreceni Egyetemen - Nyíregyháza

\begin{tabular}{|c|l|c|c|}
\hline Rangsor & Értékkör & Átlag & Szórás \\
\hline 1. & Altruizmus & 13,30 & 1,685 \\
\hline 2. & Társas kapcsolatok & 12,33 & 1,901 \\
\hline 3. & Önérvényesítés & 12,24 & 1,850 \\
\hline 4. & Presztízs & 12,14 & 1,930 \\
\hline 5. & Változatosság & 11,96 & 1,914 \\
\hline 6. & Anyagiak & 11,65 & 2,535 \\
\hline 7. & Munkateljesítmény & 11,44 & 2,778 \\
\hline 8. & Hierarchia & 11,27 & 1,996 \\
\hline 9. & Függetlenség & 11,26 & 1,889 \\
\hline 10. & Szellemi ösztönzés & 10,67 & 2,002 \\
\hline 11. & Kreativitás & 10,64 & 2,473 \\
\hline 12. & Irányítás & 9,53 & 2,570 \\
\hline 13. & Esztétikum & 9,38 & 2,206 \\
\hline 14. & Humán értékek & 8,73 & 2,106 \\
\hline 15. & Játékosság & 7,25 & 2,531 \\
\hline
\end{tabular}

Forrás: TÁMOP 4.2.2. B pályázat adatbázisa

A kolozsvári hallgatók által legfontosabbnak tartott érték a presztízs 11,95-ös átlaggal, majd ezt követi az altruizmus és a kreativitás. Az utolsó helyeket a szellemi ösztönzés, humán értékek és a játékosság kapta. Egymástól nagy különbséggel szerepel az altruizmus és a humán értékek (12). (7. táblázat) 


\section{A két rangsor összevetése}

Mind a két mintán előkelő helyet ért el az altruizmus. A továbbiakban azonban nagy különbségek fedezhetök fel az értékkörök rangsorában. A kolozsvári hallgatók kevésbé részesítik előnyben az önérvényesítést, a változatosságot, a függetlenséget, a szellemi ösztönzést.

Közel azonos ranghelyet foglal el mind a két egyetem hallgatói között az altruizmus, a társas kapcsolatok, az anyagiak, a munkateljesítmény, és a hierarchia.

A debreceni hallgatók kevésbé tartják fontosnak a kolozsvári hallgatókhoz képest a következő értékköröket: presztízs, kreativitás, irányítás, esztétikum.

Továbbá mindannyian ugyanolyan mértékben utasítják el a humán értékek és a játékosság értékeket. (8. táblázat)

7. táblázat Az értékkörök rangsora a Babeş-Bolyai Tudományegyetemen - Kolozsvár

\begin{tabular}{|c|l|c|c|}
\hline Rangsor & Értékkör & Átlag & Szórás \\
\hline 1. & Presztízs & 11,95 & 2,990 \\
\hline 2. & Altruizmus & 11,93 & 2,917 \\
\hline 3. & Kreativitás & 11,84 & 2,641 \\
\hline 4. & Társas kapcsolatok & 11,62 & 2,822 \\
\hline 5. & Irányítás & 11,27 & 2,684 \\
\hline 6. & Hierarchia & 11,26 & 2,819 \\
\hline 7. & Anyagiak & 11,25 & 3,036 \\
\hline 8. & Munkateljesítmény & 10,97 & 2,527 \\
\hline 9. & Önérvényesítés & 10,85 & 2,665 \\
\hline 10. & Esztétikum & 10,84 & 2,677 \\
\hline 11. & Függetlenség & 10,53 & 2,651 \\
\hline 12. & Változatosság & 10,40 & 2,832 \\
\hline 13. & Szellemi ösztönzés & 10,33 & 2,544 \\
\hline 14. & Humán értékek & 9,30 & 2,670 \\
\hline 15. & Játékosság & 8,30 & 2,596 \\
\hline For
\end{tabular}

Forrás: TÁMOP 4.2.2. B pályázat adatbázisa 
8. táblázat A ranghelyek összehasonlítása

\begin{tabular}{|l|c|c|c|}
\hline Értékkör & $\begin{array}{c}\text { Rangsor } \\
\text { Debrecen }\end{array}$ & $\begin{array}{c}\text { Rangsor } \\
\text { Kolozsvár }\end{array}$ & Különbség \\
\hline Altruizmus & 1. & 2. & -1 \\
\hline Társas kapcsolatok & 2. & 4. & -2 \\
\hline Önérvényesítés & 3. & 9. & -6 \\
\hline Presztízs & 4. & 1. & 3 \\
\hline Változatosság & 5. & 12. & -7 \\
\hline Anyagiak & 6. & 7. & -1 \\
\hline Munkateljesítmény & 7. & 8. & -1 \\
\hline Hierarchia & 8. & 6. & 2 \\
\hline Függetlenség & 9. & 11. & -3 \\
\hline Szellemi ösztönzés & 10. & 13. & -3 \\
\hline Kreativitás & 11. & 3. & 8 \\
\hline Irányítás & 12. & 5. & 7 \\
\hline Esztétikum & 13. & 10. & 3 \\
\hline Humán értékek & 14. & 14. & - \\
\hline Játékosság & 15. & 15. & - \\
\hline
\end{tabular}

Forrás: TÁMOP 4.2.2. B pályázat adatbázisa

\section{Iskolai végzettség és értékkörök}

Az alacsonyabb iskolai végzettséggel rendelkező édesapák gyermekei között a legpreferáltabb értékkörök a munkateljesítmény, az altruizmus és a társas kapcsolatok, legkevésbé a játékosság dominál.

A középfokú végzettséggel rendelkezők gyerekei főként az altruizmus, presztízs és társas kapcsolatok értékkörét tartották fontosnak.

A felsőfokú végzettséggel rendelkezők gyerekei számára pedig a szellemi ösztönzés, altruizmus és önérvényesítés bizonyult fontosnak. (9. táblázat) 
A debreceni mintán nem tapasztalható nagy különbség az apák végzettsége és a preferált értékek között. Minden végzettségi szinten nagy átlagot ért el az altruizmus, ami adódhat abból is, hogy a kérdések a segítő szakmát tanuló hallgatók körében lettek felvéve. Továbbá szintén nagy arányban választották a presztízs értékkörét is.

9. táblázat Az apák iskolai végzettsége és az értékkörök átlaga a Babeş-Bolyai Tudományegyetemen

\begin{tabular}{|l|c|c|c|c|c|c|}
\hline & $\begin{array}{c}\text { nem befe- } \\
\text { jezett ele- } \\
\text { mi és álta- } \\
\text { lános }\end{array}$ & $\begin{array}{c}\text { befejezett } \\
\text { álalános, } \\
\text { elemi }\end{array}$ & $\begin{array}{c}\text { szak- } \\
\text { munkás, } \\
\text { tanonc }\end{array}$ & $\begin{array}{c}\text { érett- } \\
\text { ségi }\end{array}$ & föiskola & egyetem \\
\hline Szellemi ösztönzés & 10,33 & 11,8 & 9,44 & 10,81 & 11,17 & 12,25 \\
\hline Altruizmus & 13,67 & 12,4 & 11,22 & 12,71 & 10,67 & 11,75 \\
\hline Anyagiak & 11,33 & 11,2 & 11,11 & 11,62 & 10,83 & 10,5 \\
\hline Változatosság & 13 & 10,6 & 9,78 & 10,76 & 10,5 & 11,25 \\
\hline Függetlenség & 11,33 & 11,2 & 10,06 & 10,67 & 10,83 & 12,25 \\
\hline Presztízs & 13 & 11,4 & 11,39 & 12,76 & 13,17 & 11,5 \\
\hline Esztétikum & 12 & 10,4 & 10,33 & 11,33 & 11,67 & 10,5 \\
\hline Társas kapcsolatok & 13,33 & 11,6 & 10,89 & 12,33 & 12,83 & 11,5 \\
\hline Játékosság & 7,33 & 8,8 & 8,67 & 8,57 & 8,5 & 7 \\
\hline Önérvényesítés & 11,33 & 10,8 & 10,33 & 11,33 & 11,83 & 12 \\
\hline Hierarchia & 13,67 & 11,4 & 10,72 & 11,86 & 12 & 8,5 \\
\hline Humán értékek & 10,33 & 10 & 8,67 & 9,52 & 10,5 & 7,5 \\
\hline Munkateljesítmény & 13,67 & 11,2 & 10,39 & 11,48 & 11,5 & 10,5 \\
\hline Irányítás & 13 & 12,2 & 10,28 & 11,67 & 11,33 & 11,25 \\
\hline Kreativitás & 11,67 & 12,4 & 11,17 & 12,14 & 12,83 & 10,75 \\
\hline
\end{tabular}

Forrás: TÁMOP 4.2.2. B pályázat adatbázisa

Az egyetemi végzettséggel bíró apák gyermekei fontosak tartották a változatosságot és a függetlenséget is.

Szintén minden végzettségi szinten, a legkevésbé kedvelt érték a játékosság volt, majd ezt követi a humán értékek és az esztétikum. (10. táblázat) 
10. táblázat Az édesapák iskolai végzettsége

és az értékkörök átlaga a Debreceni Egyetemen

\begin{tabular}{|l|c|c|c|c|c|c|}
\hline & $\begin{array}{c}\text { befejezett } \\
\text { általános, } \\
\text { elemi }\end{array}$ & polgári & $\begin{array}{c}\text { szak- } \\
\text { munkás, } \\
\text { tanonc }\end{array}$ & $\begin{array}{c}\text { érett- } \\
\text { ségi }\end{array}$ & föiskola & egyetem \\
\hline Szellemi ösztönzés & 9,86 & 10 & 10,61 & 11,14 & 11 & 10,6 \\
\hline Altruizmus & 13,71 & 12 & 13,45 & 13,18 & 15 & 12,2 \\
\hline Anyagiak & 11,43 & 10 & 11,61 & 12,39 & 8,5 & 10 \\
\hline Változatosság & 11,86 & 12 & 11,8 & 12,07 & 12,5 & 13 \\
\hline Függetlenség & 11,14 & 10 & 10,96 & 11,82 & 11,5 & 12,2 \\
\hline Presztízs & 12 & 12 & 12,09 & 12,5 & 13 & 11,2 \\
\hline Esztétikum & 8,14 & 8 & 9,52 & 9,39 & 12,5 & 7,8 \\
\hline Társas kapcsolatok & 11,86 & 10 & 12,52 & 12,07 & 12,5 & 12,6 \\
\hline Játékosság & 7,29 & 7 & 7,38 & 7,04 & 7 & 7,2 \\
\hline Önérvényesítés & 11,71 & 11 & 12,34 & 12,18 & 14 & 12,4 \\
\hline Hierarchia & 10,29 & 5 & 11,39 & 11,46 & 13 & 11,2 \\
\hline Humán értékek & 8,86 & 8 & 8,82 & 8,89 & 9,5 & 7,8 \\
\hline Munkateljesítmény & 10,57 & 8 & 11,38 & 12,21 & 11,5 & 9,4 \\
\hline Irányítás & 10 & 9 & 9,02 & 10,57 & 10,5 & 10,2 \\
\hline Kreativitás & 10,86 & 9 & 10,43 & 11,04 & 12,5 & 10,2 \\
\hline
\end{tabular}

Forrás: TÁMOP 4.2.2. B pályázat adatbázisa

Általánosságban elmondható, hogy az anyák iskolai végzettségétől függetlenül az altruizmus mindig magas értéket vett fel.

Azoknak az édesanyáknak a gyermekei, akik semmilyen végzettséggel sem bírnak legnagyobb arányban a presztízs, az altruizmus és társas kapcsolatok értékköröket preferálták.

A általános iskolai bizonyítványt kapott anyák gyerekei az anyagiakat és a kreativitást tartják fontosnak, a szakmunkás és érettségi bizonyítvánnyal rendelkezőknél a presztízs, társas kapcsolatok és a kreativitás kap nagy hangsúlyt, míg a felsőfokú okta tásban részt vett anyák gyerekeinél a függetlenség, az önérvényesítés, presztízs és irányítás dominál. (11. táblázat) 
11. táblázat Az édesanyák legmagasabb iskolai végzettsége és az értékkörök átlaga a Babeş-Bolyai Tudományegyetemen

\begin{tabular}{|l|c|c|c|c|c|c|}
\hline & $\begin{array}{c}\text { nem befe- } \\
\text { jezett ele- } \\
\text { mi és álta- } \\
\text { lános }\end{array}$ & $\begin{array}{c}\text { befejezett } \\
\text { általános, } \\
\text { elemi }\end{array}$ & $\begin{array}{c}\text { szak- } \\
\text { munkás, } \\
\text { tanonc }\end{array}$ & $\begin{array}{c}\text { érett- } \\
\text { ségi }\end{array}$ & föiskola & egyetem \\
\hline Szellemi ösztönzés & 10 & 9,67 & 9,71 & 11,2 & 11 & 11,88 \\
\hline Altruizmus & 12,67 & 11,67 & 11,88 & 12,6 & 9,75 & 12,25 \\
\hline Anyagiak & 10,5 & 12 & 11,24 & 11,53 & 13 & 10,38 \\
\hline Változatosság & 11,5 & 8,33 & 10,24 & 10,8 & 9,25 & 11,63 \\
\hline Függetlenség & 11,33 & 9,33 & 9,94 & 10,2 & 12,75 & 11,88 \\
\hline Presztízs & 12,83 & 10,33 & 12,18 & 12,07 & 13,25 & 12,25 \\
\hline Esztétikum & 10,83 & 11 & 10 & 11,07 & 12 & 11,13 \\
\hline Társas kapcsolatok & 12,5 & 11 & 11,29 & 12,13 & 12,25 & 11,75 \\
\hline Játékosság & 8,33 & 9 & 8,94 & 8,4 & 9,25 & 7,13 \\
\hline Önérvényesítés & 11,67 & 10,33 & 10,59 & 10,67 & 13,25 & 12 \\
\hline Hierarchia & 11 & 10,67 & 11,24 & 11,87 & 12,25 & 10 \\
\hline Humán értékek & 7,83 & 8,67 & 9,35 & 10,07 & 9 & 9,13 \\
\hline Munkateljesítmény & 12,33 & 10,67 & 10,71 & 11,27 & 11,25 & 10,63 \\
\hline Irányítás & 10,83 & 11,67 & 10,29 & 11,8 & 12,75 & 11,88 \\
\hline Kreativitás & 12,17 & 12,67 & 11,53 & 11,93 & 12,25 & 11,75 \\
\hline Foras: TÁMOP 42.8 & & & & \\
\hline
\end{tabular}

Forrás: TÁMOP 4.2.2. B pályázat adatbázisa

Az alapfokú oktatást kapott édesanyák gyerekei a társas kapcsolatokat és az önérvényesítést, a középfokú képzésben részt vettek a társas kapcsolatokat, anyagiakat, az önérvényesítést és a presztízst, a felsőfokú képzésben részesült anyák gyermekei pedig a presztízst, az önérvényesítést és a társas kapcsolatokat tartották fontosnak az altruizmuson kívül. (12. táblázat) 
12. ábra: Az édesanyák legmagasabb iskolai végzettsége és az értékkörök átlaga a Debreceni Egyetemen

\begin{tabular}{|l|l|l|l|l|l|} 
& $\begin{array}{l}\text { befejezett } \\
\text { általános, } \\
\text { elemi }\end{array}$ & $\begin{array}{l}\text { szakmun- ta- } \\
\text { nonc }\end{array}$ & érettségi & föiskola & egyetem \\
\hline Szellemi ösztönzés & 10,3 & 10,52 & 10,57 & 11,73 & 11,14 \\
\hline Altruizmus & 13,4 & 13,64 & 13,17 & 13,27 & 13,29 \\
\hline Anyagiak & 11,4 & 12,32 & 11,55 & 11,91 & 10,14 \\
\hline Változatosság & 11 & 12,24 & 11,91 & 12,82 & 11,43 \\
\hline Függetlenség & 10,8 & 11,6 & 11,04 & 11,82 & 11,57 \\
\hline Presztízs & 11,3 & 12,44 & 12,15 & 13 & 11,29 \\
\hline Esztétikum & 9 & 9,8 & 9,02 & 10,09 & 9 \\
\hline Társas kapcsolatok & 12,4 & 12,72 & 12 & 12,91 & 12,14 \\
\hline Játékosság & 6,2 & 7,8 & 7,06 & 7,18 & 7,86 \\
\hline Önérvényesítés & 11,6 & 12,2 & 12,19 & 13,45 & 12,29 \\
\hline Hierarchia & 11,1 & 11,32 & 11,36 & 11,09 & 10,86 \\
\hline Humán értékek & 8,3 & 8,8 & 8,96 & 7,64 & 9,43 \\
\hline Munkateljesítmény & 10,4 & 11,32 & 11,7 & 11,55 & 11,29 \\
\hline Irányítás & 8,4 & 9,72 & 9,79 & 9,91 & 9,14 \\
\hline Kreativitás & 10,3 & 10,96 & 10,4 & 12,09 & 9,43 \\
\hline
\end{tabular}

Forrás: TÁMOP 4.2.2. B pályázat adatbázisa

Összességében megállapítható, hogy a szülök iskolai végzettségétől és a hallgatók nemzetiségétől függetlenül az altruizmust minden diák nagyon fontosnak tartja, továbbá a leggyengébb értékeknek az esztétikum, a játékosság és a humán értékek bizonyultak.

A varimax rotált faktorsúly mátrixok alapján a kolozsvári almintában négy, a nyíregyháziban pedig öt faktor különült el. 
A Babeş-Bolyai Tudományegyetem hallgatóinak Super munkaérték rotált faktorsúly mátrixai:

1. faktor - Az első faktorba a hierarchia, a társas kapcsolatok, munkateljesítmény és az altruizmus értékkörök tartoznak.

\begin{tabular}{|l|c|}
\hline Értékkör & Faktorsúly \\
\hline hierarchia & .698 \\
\hline társas kapcsolatok & .696 \\
\hline munkateljesítmény & .620 \\
\hline altruizmus & .531 \\
\hline
\end{tabular}

2. faktor - A második faktorba a változatosság, kreativitás és szellemi ösztönzés tartozik. Az igen nagy faktorsúllyal szereplö változatosság az értékkörök rangsorában csupán a 12 . helyet kapta.

\begin{tabular}{|l|c|}
\hline Értékkör & Faktorsúly \\
\hline változatosság & .753 \\
\hline kreativitás & .658 \\
\hline szellemi ösztönzés & .588 \\
\hline
\end{tabular}

3. faktor - A harmadik faktorban az irányítás, az anyagiak és a presztízs szerepel. Itt a legkisebb faktorsúlyt kapott presztízs az értékkörök rangsorában az első, míg az irányítás és az anyagiak a középmezőnyben állnak.

\begin{tabular}{|l|c|}
\hline Értékkör & Faktorsúly \\
\hline irányítás & .786 \\
\hline anyagiak & .742 \\
\hline presztízs & .557 \\
\hline
\end{tabular}

4. faktor - Ebbe a faktorba a játékosság, az esztétikum és az önérvényesítés kapott helyett.

\begin{tabular}{|l|l|}
\hline Értékkör & Faktorsúly \\
\hline játékosság & .730 \\
\hline esztétikum & .663 \\
\hline önérvényesítés & .609 \\
\hline
\end{tabular}


A Debreceni Egyetem Egészségügyi Kar rotált faktorsúly mátrixai:

1. faktor - Az első faktorban az anyagiak, az irányítás, a presztízs és a függetlenség szerepel, mind igen magas faktorsúllyal.

\begin{tabular}{|l|l|}
\hline Értékkör & Faktorsúly \\
\hline anyagiak & .739 \\
\hline irányítás & .728 \\
\hline presztízs & .727 \\
\hline függetlenség & .701 \\
\hline
\end{tabular}

2. faktor - A második faktorba két értékkör tartozik: humán értékek és játékosság. Mind a két érték igen magas faktorsúllyal szerepel, azonban az értékkörök rangsorában az utolsó két helyet kapták.

\begin{tabular}{|l|l|}
\hline Értékkör & Faktorsúly \\
\hline humán értékek & .823 \\
\hline játékosság & .752 \\
\hline
\end{tabular}

3. faktor - A harmadik faktorban szereplő altruizmus és társas kapcsolatok az értékkörök között az első két helyen áll, a munkateljesítmény és az esztétikum pedig a kevésbé preferált értékek .

\begin{tabular}{|l|l|} 
Értékkör & Faktorsúly \\
\hline altruizmus & .770 \\
\hline munkateljesítmény & .676 \\
\hline társas kapcsolatok & .557 \\
\hline esztétikum & .550 \\
\hline
\end{tabular}

4. faktor - Ebbe a faktorba a hierarchia, az önérvényesítés és a társas kapcsolatok tartozik.

\begin{tabular}{|l|l|}
\hline Értékkör & Faktorsúly \\
\hline hierarchia & .806 \\
\hline önérvényesítés & .636 \\
\hline társas kapcsolatok & .528 \\
\hline
\end{tabular}


5. faktor - Az utolsó faktorba a változatosság és a szellemi ösztönzés foglal helyet.

\begin{tabular}{|l|l|}
\hline Értékkör & Faktorsúly \\
\hline változatosság & .747 \\
\hline szellemi ösztönzés & .723 \\
\hline
\end{tabular}

A két minta eredményei alapján nagyjából hasonló faktorokat kaptunk.

A kolozsvári első faktor ( hierarchia, társas kapcsolatok, munkateljesítmény, altruizmus) a debreceni harmadik faktorral( altruizmus, munkateljesítmény, társas kapcsolatok, esztétikum) mutat hasonlóságot.

A román második faktor (változatosság, kreativitás, szellemi ösztönzés), a magyar ötödik faktorral ( változatosság, szellemi ösztönzés) kapcsolható össze. Ezeket a faktorokat ,alkotásnak” hívnám

A román harmadik faktor ( irányítás, anyagiak, presztízs) a magyar első faktorral ( anyagiak, irányítás, presztízs, függetlenség) hasonlíthatjuk össze. Ezt a két faktort „vezető"-nek nevezném el.

A kolozsvári negyedik faktort ( játékosság, esztétikum, önérvényesítés) a magyar második faktorral ( humán értékek, játékosság) állítanám összefüggésbe

\section{ÖssZEGZÉS}

Kutatásunk során közel azonos arányban kaptunk vissza kitöltött kérdőíveket a kolozsvári egyetem román nyelvű képzésében résztvevő diákoktól és a debreceni hallgatóktól, illetve várakozásunknak megfelelően a mintánkon is megfigyelhető az elnőiesedés jelensége, amit már számos korábbi tanulmány is mutatott (pl: Kiss, 2008).

A hallgatók többsége a humán és segítő szakmák valamelyikét tanulja, a debreceniek közül mindenki ezen csoportba tartozik, a kolozsvári hallgatók 80,3\%-a szociális munkás szakos.

Az iskolai életút tekintetében nem mondható ki számottevő különbség, mind a két alminta hallgatói nagyrészt állami/ önkormányzati fenntartású iskolában végezte az alapfokú tanulmányait, a magán képzésben résztvevők alacsony száma magyarázható azzal, hogy kevesen engedhetik meg anyagilag maguknak, hogy gyermekeiket ilyen típusú iskolába írassák, továbbá a vizsgált területeken kevésbé elterjedt ez a fajta oktatás, mint tőlünk nyugati országokban.

Általánosságban elmondható, hogy mind a két nemzet hallgatói legnagyobb arányban gimnáziumokban végezték középfokú tanulmányaikat. Különbség tapasztalható a szakközépiskola tekintetében, hiszen a magyarok közül igen sokan végeztek ilyen típusú iskolát, míg a román hallgatók közül csupán hárman.

A hallgatók lakóhelyével kapcsolatban azonosságok fedezhetőek fel a két minta között, a diákok fele a szüleivel egy háztartásban lakik és közel azonos arányban laknak albérletben és kollégiumban. 
Az önálló háztartást fenntartók alacsony száma nem meglepö, hiszen a hallgatók nagy része a 18-25 éves korosztályba tartozik, és valószínüleg nem rendelkeznek saját bevételi forrással.

Az értékkörök rangsorában érdekes eltérések tapasztalhatóak a román és magyar minta között.

A legnagyobb különbséget mutató értékkörök a következők. Az önérvényesítés a magyar hallgatók által egyik legpreferáltabb értékkör, míg a román minta rangsorában csupán a kilencedik helyen áll. A változatosság a magyar mintán a középmezőnyben található, míg a román mintán a kevésbé domináns értékkörök közé sorolható. A kreativitás, valami újnak az alkotása, létrehozása a román hallatók számára sokkal fontosabbnak bizonyult, mint a magyar társaiknak, hiszen a rangsorban 7 hellyel magasabban értékelték azt. Az irányítást a román hallgatók részesítik előnyben az olyan típusú munkáknál, ahol másokat vezethetnek, míg a magyar diákoknál az irányítás az elutasított értékkörök közé tartozik. Lássuk a hasonlóságokat az értékkörök rangsorában. Mindkét hallgatócsoport rangsorában előkelő helyen szerepel az altruizmus, az önzetlenül másokon való segítés értékköre, ami már-már (el)várható a segítő szakmát tanulók körében. Szintén fontosnak tartották a társas kapcsolatokat, a valahová tartozást és a presztízst. Hasonlóságot mutatnak az elutasított értékkörök is, így az esztétikum, a humán értékek, és a játékosság.

Az apák iskolai végzettsége és a preferált értékkörök közötti vizsgálat során megállapítható, hogy a nemzetiségtől és végzettségtől függetlenül mindannyian fontosnak tartották az altruizmust és a presztízst.

Az anyák iskolai végzettsége és preferált értékkörök közötti kapcsolat vizsgálata során kijelenthetjük, hogy a román minta tekintetében nincs szignifikáns különbség, szinte minden szinten az altruizmust, presztízst és a társas kapcsolatokat tartották fontosabbnak. Egyedül a középszintü iskolát végzetteknél domináns a kreativitás és a felsőfokú iskolát végzett anyák esetében az önérvényesítés.

A magyar mintát nézve is hasonló kijelentéseket tehetünk, kiegészítve az önérvényesítés értékkörével. 


\section{Felhaszálet irodalom}

Fónai Mihály- Kiss János- Fábián Gergely: Szociális munkás szakos hallgatók pályaképének néhány eleme. Esély, 1999. /1. 114 - 134 o.

Kiss János: : Szociális munkás szakos hallgatók munkaérték preferenciáinak nemzetközi összehasonlítása, „Peremvidék” Szociális kutatások Szabolcs-Szatmár-Bereg megyében. DOTE Egészségügyi Főiskolai Kar- Salgótarjáni Népjóléti Képzési Központ, Nyíregyháza, Salgótarján, 1999. 251- 277 o.

Kiss János: Munkaérték preferenciák összehasonlító vizsgálata szociális munkás hallgatóknál. DOTE E.F.K. Tudományos Közleményei, Nyíregyháza, 1998.1. 411 - 435 o.

Kiss János: Munkaérték preferenciák strukturális változásai a professzionalizáció mértékének és a képzés tartalmi változásainak tükrében. Debreceni Egyetem BTK, doktori értekezés, 2008.

Kiss János: Szociális munkás hallgatók pályaképe kultúrközi összehasonlító vizsgálatokból, Munkalélektani Koordináló Tanács Munkalélektani Füzetek 1995. 125 - 134 o.

Kiss János: Szociális munkás szakos hallgatók pálya és társadalomképének néhány eleme, Társadalmi szolidalitás fejlesztése Kelet-Közép-Európában Debrecen KLTE 2000. 